\title{
Entanglements of Economic and Intimate Citizenship: Individualization and Gender (In)Equality in a Changing Europe
}

\section{Nicky Le Feuvre ${ }^{1}$ and Sasha Roseneil ${ }^{*}$}

This paper contributes to the ongoing refinement of citizenship as a feminist concept through the development of understandings of the relationship between economic and intimate citizenship in contemporary Europe. It draws on two crossnational research projects that each focus on a group of people who might be thought to be affected by particular processes of individualization: the economic "activation" of large numbers of women in increasingly deregulated labour markets, and the progressive detraditionalization of intimate life. The paper examines patterns of intimate life and citizenship that accompany employment in the elder care sector, and patterns of economic life and citizenship that accompany the experience of living outside the conventional family. It argues that there are significant and hitherto unrecognized tensions between "flexible" jobs and the ability of individuals to exercise agency as intimate citizens. It suggests that it is difficult to flourish as an intimate citizen without enjoying a degree of economic autonomy, and that economic autonomy is elusive for women working in the most deregulated sectors of the labour market. It also points to the important role that social policies play in mediating the relationship between intimate and economic citizenship.

\section{Introduction}

In recent years citizenship has proved a productive terrain of inquiry for feminist social scientists. Having developed powerful gender critiques of classical, republican, and liberal theorizations of citizenship, many feminist scholars have embraced the concept for its potential to offer a lens on a wide ranging set of practices and processes of inclusion and exclusion, recognition and misrecognition, participation and belonging, freedom and oppression, in

\footnotetext{
${ }^{1}$ University of Lausanne.

${ }^{2}$ Birkbeck, University of London.

*s.roseneil@bbk.ac.uk 
relation to state, civil society and everyday life (Cossman 2007; Friedman 2005; Halsaa, Roseneil, and Sümer 2012; Lister 1997; Lister et al. 2007; Pettman 1999; Roseneil 2013; Siim 2000; Siim and Squires 2008; Yuval-Davis 1997). As such it is a concept that lends itself to both empirical investigation and normative evaluation and critique. Moreover, the extensive "policy purchase" of the notion of citizenship across an increasingly multicultural and diverse Europe has given added impetus to studies of contemporary formations of citizenship and to attempts to utilize the concept to bring feminist futures into being (Halsaa, Roseneil, and Sümer 2012). In this paper we contribute to this growing body of research by focusing on the interrelationships between two aspects of citizenship that are relatively under-developed in the literature-economic and intimate citizenship.

The paper draws on work carried out as part of FEMCIT, an EU-funded research project that explored changing practices of gendered citizenship in Europe in the light of the demands that have emerged from women's movements. ${ }^{1}$ In this, FEMCIT foregrounded the question of agency-investigating both the collective agency of women's movements in transforming the meanings and lived realities of citizenship, and the potential agency of, and impediments to agency for, people-particularly women—in their everyday lives. Developing a feminist understanding of citizenship inspired by the struggles of women's movements to politicize and transform inequality and injustice across all areas of social life, FEMCIT pursued a multi-dimensional approach to the analysis of contemporary citizenship. The research team carried out a number of separate empirical studies along six dimensions of gendered citizenship-political, social, economic, multicultural, bodily, and intimate citizenship (Halsaa, Roseneil, and Sümer 2011, 2012). Whilst FEMCIT argued that these dimensions of citizenship are fundamentally interconnected, the exigencies of the research design meant that, in practice, we tended to treat them as distinct and separate. Here, however, we grapple with the challenge of taking seriously the FEMCIT argument about the interconnectedness of the dimensions of citizenship that we have been studying.

Our particular concern is to explore the entanglements and co-production of economic and intimate citizenship that emerge in the context of contemporary processes of individualization in economic and intimate life in the geotemporality of contemporary Europe. Specifically, we focus on the increasing deregulation and flexibilization of labour markets (Beck 2000; Castel 1995; Sennett 1998), the detraditionalization of intimate lives (Beck and Beck-Gernsheim 2002; Giddens 1992, 1994; Heelas, Lash, and Morris 1996) and the increasing prevalence of lives led outside the conventional heterosexual couple form (Roseneil 2000; Roseneil and Budgeon 2004). Ulrich Beck, one of the leading proponents of the "individualization thesis" in European social theory argues that late or "second" modernity has largely "freed people from historically inscribed roles" (Beck 2002, 202-203). He presents the detraditionalization of intimate life and the flexibilization of labour markets as two 
defining characteristics of the individualization process that are central to the current epoch. On the one hand, "women are cut loose from their 'status fate' of compulsory housework and support by a husband" and, on the other hand, "the old forms of work routine and discipline are in decline with the emergence of flexible work hours, pluralized underemployment and the decentralization of work sites" (Beck 2002, 202-203). This process is also accompanied by what Beck calls a "new standardization", whereby " $[\mathrm{t}]$ he individual is removed from traditional commitments and support relationships, but exchanges them for the constraints of existence in the labour market" (Beck 2002, 203).

In this article, we stage an encounter between two FEMCIT sub-projects, each of which focused on a group of people who might be thought of as prime exemplars of these highly gendered transformations in economic and intimate life: workers in the elder care sector and people living outside conventional families. The economic citizenship project was concerned with the defamilialization of elder care and the deregulation of labour markets, and sought to develop a feminist conceptualization of economic citizenship. ${ }^{2}$ The intimate citizenship project was concerned with the proliferation of lives being led outside the normative heterosexual couple and family, and sought to develop a feminist conceptualization of intimate citizenship. ${ }^{3}$ In bringing the projects into dialogue, we discuss the patterns of intimate life and citizenship that accompany employment in the rapidly growing elder care sector, and the patterns of economic life and citizenship that accompany the experience of living outside the conventional family. We suggest that there are significant and largely unexplored tensions between the different facets of individualization on which we have focused, and that this has important implications for understandings of contemporary experiences of citizenship and for the prospects of gender (in)equality in Europe. Through the paper's cross-national, comparative lens, we point to the importance of national-level social citizenship policies and welfare regimes in mediating the relationship between economic and intimate citizenship.

\section{Theoretical Contextualization}

\section{Entanglements of Economic and Intimate Citizenship in Historical Feminist Perspective}

Despite the relative novelty of the concepts of economic and intimate citizenship, our interest in exploring their mutual entanglement can be seen as part of a broader project with a long history that can be traced back through feminism, Marxism and, more recently, sexuality studies. As early as the end of the eighteenth century, Mary Wollstonecraft (1792) had argued that no woman could truly be free to marry until she was economically able to remain single. A century later, many first-wave feminist campaigners across Europe were engaged in struggles to secure women's access to higher education and 
the labour market (Offen 2000; Schweitzer 2002), in the name of the increasing numbers of unmarried women of bourgeois backgrounds - the "superfluous women"-who had no male wage to support them and who were ineligible for the apprenticeships and professional qualifications that might enable them to earn an adequate living. Josephine Butler, for instance, said:

I cannot believe it is every woman's duty to marry, in this age of the world. There is an abundance of work to be done which needs men and women detached from domestic ties; our unmarried women will be the greatest blessing to the community when they cease to be soured by disappointment or driven by destitution to despair $(1869, \mathrm{xxxv}$, cited in Uglow 1983, 153).

More radical first-wave feminists developed an analysis of marriage and the inherently dependent status of the wife as central to women's oppression, and as comparable with prostitution. Christabel Pankhurst, for instance, regarded it as "the man's instinctive endeavour [...] to keep the woman in a state of economic dependence. This desire to keep women in economic subjection to themselves - to have women, as it were, at their mercy - is at the root of men's opposition to the industrial and professional employment of women" (1913, 43-4, cited in Sarah 1983, 270).

These first-wave women's movement claims were echoed in the writings of activists and scholars of the second-wave movement for whom women's exclusion from the right to earn a living wage was understood as directly related to the institutionalization of heterosexual marriage as the dominant form of intimate relationship. For instance, Juliet Mitchell's (1966) ground-breaking statement of socialist feminist theory understood women's condition through the analysis of four structures-production, reproduction, socialization, and sexuality-emphasizing their interrelatedness:

The contemporary bourgeois family can be seen as a triptych of sexual, reproductive and socializatory functions (the woman's world) embraced by production (the man's world) - precisely a structure which in the final instance is determined by the economy. The exclusion of women from production - social human activity - and their confinement to a monolithic condensation of functions in a unity - the family - [...] is the root cause of the contemporary social definition of women as natural beings. Hence the main thrust of any emancipation movement must still concentrate on the economic element - the entry of women fully into public industry [...] Economic demands are still primary, but must be accompanied by coherent policies for the other three elements (Mitchell 1966, 34).

Resonating with this, but refusing to analytically prioritize the economic sphere, the seven demands of the British women's liberation movement, which had been developed by 1978, included a focus on both issues of 
economic and intimate citizenship, with the 5th demand, for "legal and financial independence for all women" as a key linking demand. ${ }^{4}$ Many European feminist theorists (e.g. Delphy 1970; Guillaumin 1992; Leonard and Allen 1991) also stressed the complex gendered intertwinement of economic and intimate life, and "women's law" theorist, Tove Stang Dahl (1987) has argued that an independent income is a "necessary prerequisite for personal freedom, self-determination and self-realisation" $(1987,91)$ —in private as well as public life.

More recently, the relationship between economic life and intimate life for those living outside normative heterosexuality has become an important topic within sexuality studies and queer theory (see Bedford and Jakobsen 2009). There is a body of sociological work that has traced the historical relationship between the development of capitalism, processes of urbanization, the detraditionalization of family life, and the emergence of gay communities and identity (e.g. Adam 1995; Bech 1997; D'Emilio 1983). Others theorists have been grappling, more or less explicitly, with the Marxist problematic of the relationship between economy and culture, as, for instance, in the debate between Judith Butler (1998) and Nancy Fraser (1998) about whether sexuality should be understood as "merely cultural", and the work of David Evans (1993), Donald Morton (1996), Rosemary Hennessy (2000), Yvette Taylor (2007) and Brian Heaphy (2011), amongst others, has demanded attention to the role of class and material inequality in lesbian and gay lives.

\section{Entanglements of Economic and Intimate Citizenship in Contemporary Welfare Research}

In contrast both with the emphasis placed by many feminists historically on the relationship between access to independent, adequate economic resources through labour market participation and self-determination in intimate life, and the relationship identified by theorists of late or second modernity between the increase in women's economic independence and the detraditionalization of intimate life (Beck and Beck-Gernsheim 1995, 2002; Giddens 1992, 1994), concern with the entanglement of economic and intimate citizenship has not featured prominently on the agendas of welfare state researchers. Following Gosta Esping-Andersen's (1990) first typology of welfare regimes, feminist critiques centred—justifiably—on his lack of attention to the un-paid care activities carried out by women in the domestic sphere (Daly and Rake 2003; Lewis 1992; Pfau-Effinger and Geissler 2005) and on the influence of these on their access to welfare benefits. Although some of the critical assessments of the initial welfare regimes typology did focus on their differential effects on women in particular kinds of living arrangements (particularly on lone mothers) (Daly 1994; Duncan and Edwards 1997, 1999; Lewis 1997), the increasing diversity of intimate lives, and in particular the increase in the proportion of the population spending significant parts of their lives outside the conventional heterosexual cohabiting couple form (Roseneil 2000) has never 
been a central consideration. ${ }^{5}$ For instance, whilst Lynn Prince Cooke and Janeen Baxter (2010) provide a comprehensive review of the relationship between welfare regimes, gender equality and family formation patterns, arguing convincingly that the "policy context $[\ldots]$ provides an excellent indicator of the macro environment in which individuals live, love, and labour" $(2010,516)$, they restrict their analysis to heterosexual marriage and cohabitation in different national contexts, principally due to the lack of available comparative data on other, less normative, but increasingly widespread, living arrangements. ${ }^{6}$

Most of the alternative typologies of welfare regimes developed to account for their gendered characteristics have been focused on heterosexual couple living arrangements. Thus, it has been suggested that the ideological male breadwinner/female carer model of gender arrangements that dominated the second half of the twentieth century has largely been superseded by an equally normative idea(l) of the "dual breadwinner/dual carer", based on the premise that individuals will continue to live in households where two adults will divide paid and un-paid work between themselves, preferably on a relatively "de-gendered", equal and interchangeable basis (Le Feuvre 1999). Although the use of the term "dual" removes the blatant heteronormativity that infused much of the early gender and welfare states literature, this model, and those who write about it, tend to continue to assume that most individuals will be coupled and cohabiting with another adult, with whom negotiations will take place about paid work and un-paid care activities (de Singly 1987, 2000). ${ }^{7}$ Indeed, Mary Daly has observed evidence of a "renewed jointism" (Daly 2011, 16) in recent European welfare policy and research, as "the partnered couple has replaced the married couple as the reference unit" $(2011,16)$, and many policy incentives that encourage or compel women to achieve economic independence through employment continue to refer implicitly to a "dual earner, gender specialized, family model" (Daly 2011, 19), limiting the opportunities for women to achieve full citizenship beyond the (heterosexual) couple form.

Although it is generally recognized that the normative shift from the "male breadwinner/female carer" to the "adult worker" model may give rise to a series of "new social problems" (Bonoli 2005), these tend to be treated as transitional misfits, that could be resolved by the adaptation of social protection regimes to "women's new roles" (Esping-Andersen 2009). Thus, the active promotion of an "adult worker" model of citizenship (Anneseley 2007) has frequently been predicated on the increased availability of externalized and/or professionalized care services. Contrary to the claims for a fairer sharing of domestic labour and care activities between men and women that were at the heart of the second-wave women's movement (Metso et al. 2009; Stratigaki 2004), much of the redistribution of care work has taken place between different groups of women, both within Western societies and on a global scale (Ehrenreich and Hochschild 2002). However, interpretations of this 
redistribution vary considerably (Le Feuvre et al. 2012). Some authors stress the "virtuous circle" of women's emancipation through employment that occurs when some groups of women are (finally) able to adopt traditional male career paths and create new employment opportunities for less wellqualified women, by "outsourcing" part of "their" domestic responsibilities (Magnoni-d'Intagnano 1999). Other researchers have insisted on the new inequalities that emerge when less well-qualified groups of women lose all the (typically female) alternative routes to social integration outside of the labour market and are constrained to take up care jobs that leave them in a limbo of economic precariousness and of symbolic subordination to their (usually) white, middle-class female employers (Glenn 1992; Rollins 1990). According to this decidedly less "virtuous" scenario, the (partial) demise of the "male breadwinner/female carer" model of gender relations (Crompton 2006; Crompton, Lewis, and Lyonette 2007) is leading to an increase in the class and racialized differences between women.

Esping-Andersen (2009) has recently taken up this theme, arguing that the widespread "social investment" orientated policy shift to an "adult worker" model of citizenship runs the risk of creating new inequalities between women. He argues that highly qualified, middle class women are able to maintain a continuous link to the labour market, whilst also fulfilling their fertility objectives and living in relatively stable, "dual earner" (heterosexual) households, whilst this is less often the case for their working class counterparts. Not only do widespread unemployment and flexible, part-time, badly paid jobs make it difficult for poorly qualified women to conform to the new "adult worker" premises of European social protection systems, these women also experience the highest divorce/separation rates and struggle to access the economic resources required to raise their children, or even to have the desired number of offspring (Esping-Andersen 2009). Thus, middle class women "achieve" economic autonomy and conjugal stability ( partly thanks to the externalization of care activities, which means that potential conflict around the sexual division of labour can be avoided), whilst their working class counterparts "achieve" neither. One of the problematic implicit assumptions of this argument is to regard living outside the stable heterosexual couple formation as imposed, rather than chosen, and non-conventional living arrangements as necessarily problematic, and tied up with women's economic deprivation.

\section{Conceptual Contextualization}

In the burgeoning trans-disciplinary literatures that have drawn on the tripartite conceptualization of civil, political, and social citizenship proposed by Marshall (1950), there are few direct references to the notions of economic or intimate citizenship. We suggest, however, that both are central to any adequate theorization of contemporary gendered citizenship. 


\section{Economic Citizenship}

In the context of post second world war welfare states, access to economic resources has usually been subsumed under the notion of "social" or "civil" citizenship, since the right to "follow the occupation of one's choice" was defined as a basic civil right by Marshall (1950). Although, most women in the West have historically gained access to a range of social rights and benefits through marriage and/or motherhood rather than employment, this is no longer so clearly the case today (OECD 2006). Within the European Union (EU), women, particularly those with a history of discontinuous economic activity, are being targeted by policies aimed at increasing economic activity rates, under so-called activation objectives (Annesley 2007). These policies reflect the more general shift to an "adult worker" conception of citizenship (Esping-Andersen 2009; Fraser 1994, 2000; Lewis and Guillari 2005), under various "social investment" models of welfare (Jenson 2010; Méda 2010). For those who migrate from the country of their birth, it is suggested that citizenship is increasingly framed as a right to be bestowed exclusively on those individuals who have already secured access to the labour market of their host country; this is described as "earned citizenship" (van Houdt, Suvarieol, and Shinkel 2011). It thus seems necessary to distinguish more clearly between "social citizenship" issues, which refer to various social benefits, and women's direct access to rights, resources, and recognition (Lister 1997) through their own participation in paid labour.

Along with Barbara Hobson (2000) and Laura Levine Frader (2008), Alice Kessler-Harris is one of the few feminist scholars to have developed the notion of "economic citizenship", which she defines as "the right to work at the occupation of one's choice (where work includes child-rearing and household maintenance); to earn wages adequate to the support of self and family; to a non-discriminatory job market; to the education and training that facilitate access to it; to the social benefits necessary to support labour force participation; and to the social environment required for effective choice, including adequate housing, safe streets, accessible public transport, and universal health care" (Kessler-Harris 2003, 163).

Kessler-Harris shows quite clearly that if those jobs primarily labelled as "women's work" generally fail to meet the criteria for full economic citizenship, it is precisely because women have historically benefitted from three distinct sources of social protection. On the one hand, they may access benefits directly, through their own labour-market participation (putting them on a par with most men). On the other hand, they may be entitled to benefits as the spouse of an employed male partner (widow's pensions, for example) or receive direct state support (welfare transfers) on the basis of their domestic caring and household maintenance roles (carers' allowance, for example). One of the results of this has been to reduce the effectiveness of women's claims for 
economic redistribution and social recognition directly through their own employment (Kessler-Harris 2003; Le Feuvre et al. 2012).

This definition of economic citizenship allows us to consider not only the characteristics of women's jobs (levels of pay, working time patterns, health and safety issues, qualifications and training, promotion prospects, and so on), but also the ways in which these particular jobs affect women's ability to construct and maintain satisfactory relationships with their "intimate others," something which constitutes a vital dimension of economic citizenship as conceived in FEMCIT.

\section{Intimate Citizenship}

Intimate citizenship is a relatively new concept that has not as yet been widely taken up in the citizenship literature. ${ }^{8} \mathrm{~A}$ feminist concept in its explicit connection of intimate life and citizenship, it rests on the second-wave feminist claim that "the personal is political," asserting that "public" and "private" are always mutually entangled, and that there is no clear, real, or ultimate distinction to be drawn between them. Our use of the term has been influenced by the work of Ken Plummer $(1995,2003)$, who argues that intimate citizenship has emerged as a terrain of struggle, and thus as a crucial dimension of citizenship, in late modernity due to feminism and lesbian and gay movements. ${ }^{9}$ Plummer suggests that intimate citizenship is "concerned with all those matters linked to our most intimate desires, pleasures and ways of being in the world" $(1995,151)$. It is about "the control (or not) over one's body, feelings, relationships; access (or not) to representations, relationships, public spaces, etc.; and socially grounded choices (or not) about identities, gender experiences, erotic experiences" (Plummer 1995, 151). As such, Plummer suggests that intimate citizenship is an inherently and intensely subjective experience, which demands attention to practices of narrative meaning-making.

The notion of intimate citizenship suggests that the sphere of intimacy and personal life is a core arena for the exercise of "rights and responsibilities" and for experiences of "belonging and participation," which are the key elements of Lister et al.'s $(2007,168)$ understanding of citizenship. As an analytical concept, it can be understood as concerned with the processes, practices, and discourses that regulate and shape the exercise of agency in intimate life: both the laws and policies enacted by states and polities, and the social relations between individuals and groups within civil society (Roseneil et al. 2012). Intimate citizenship is about the conditions that sustain and support the development and exercise of "relational autonomy" (Mackenzie and Stoljar 2000; Roseneil 2010). As a normative concept, against which prevailing conditions might be evaluated, full intimate citizenship might be imagined as "the (as yet unachieved) freedom and ability to construct and live selfhood (understood as encompassing psychic and embodied experience) and a wide range of close relationships - sexual/love relationships, friendships, parental and kin relations, and household companionship and community - safely, securely and 
according to personal choice, in their dynamic and changing forms, with respect, recognition and support from state and civil society" (Roseneil 2010, $81-2)$. It therefore draws our attention to the relationship between experiences of intimate life and experiences of belonging and recognition in the wider social sphere, and to the ways in which people understand and make sense of these experiences.

\section{Methodology}

The overarching approach in the two FEMCIT projects was similar, although different countries were the focus in the two studies. In both cases, we were interested in taking up and testing one of the central claims of the "individualization theorists" (Beck and Beck-Gernsheim 1995, 2002; Giddens 1992) that women's movements have been central to the transformation of employment relations and intimacy under the conditions of "second" modernity. In each study, we began by mapping the claims made by contemporary (i.e. second wave) women's and other relevant social movements (particularly focusing on trade unions and LGBT groups) in relation to economic and intimate citizenship issues in contrasting European national contexts. Claims-making in relation to economic citizenship issues was studied through a content analysis of women's movement and academic Women's/Gender Studies publications (including web-sites) in Finland, France, Norway, Poland, and the UK, covering the period from the early 1970s to the present day (Metso et al. 2009). In the intimate citizenship study, an analysis was carried out, first, of the claims and demands of social movements around intimate life, and second, of law and policy relating to intimate life and citizenship over a forty-year period (19681988) in Bulgaria, Norway, Portugal, and the UK (Roseneil et al. 2008, 2009). In both studies, the countries were selected for their "most dissimilar" characteristics according to most of the existing welfare state typologies.

Both projects proceeded with a series of in-depth, biographical interviews with those individuals who could be thought to exemplify the individualization processes in which we were interested. For the economic citizenship study, this involved expert interviews with employers and trade union representatives and seventy-five life-history interviews with male and female elder care workers in France, Norway, and Poland. The interviewees were selected to cover the widest possible range of employment statuses (declared/undeclared), working hours (full/part time), job titles (geriatric nurse, home-help, care assistant, etc.), geographical location (urban/rural), and type of employer (elder care institutions, home-help agencies, municipal or voluntary sector care providers, direct employment by the care beneficiaries or their families). The intimate citizenship study involved interviews carried out according to the biographicalnarrative interpretive method (BNIM) (Wengraf 2009) with forty-one women and twenty-six men who were all "objectively individualized" - that is, they 
were all living outside the male breadwinner, or even the modified dual breadwinner, heterosexual family/cohabiting couple form, in Lisbon, London, Oslo, and Sofia. ${ }^{10}$ The interviewees were one or more of the following: single, lesbian/gay/bisexual, in a "living apart together" relationship, and/or living in shared housing. The idea here was to build a sample in which none of the women interviewees were dependent on, or sharing, a male partner's wage, and no male interviewees were supporting a female partner with whom they lived. In each project and each country, we interviewed members of the national majority and members of at least one minoritized/racialized group. ${ }^{11}$ The most significant methodological difference between the two projects as far as the analysis developed in this paper is concerned is that whereas the economic citizenship study focused on life histories, the intimate citizenship project developed an analysis of biographical narratives. ${ }^{12}$ This means that our accounts of the entanglement of economic and intimate citizenship experiences in each data set differ somewhat in focus, from a discussion of the more "objective" patterns of the relationship between economic citizenship and intimate living arrangements in the economic citizenship project, to attention to the more "subjective", narrative meaning-making and experiential aspects of the relationship between intimate and economic life in the intimate citizenship project. ${ }^{13}$

It was emergent features of the samples that we chose for each project that ultimately led us to address the entanglements of economic and intimate citizenship as a research question in its own right. The living arrangements of the elder care workers we interviewed had not been a focus of the economic citizenship study, but it soon became evident that there was a relationship between the structural characteristics of different types of elder care jobs-that is their conditions of economic citizenship - and the ability to exercise agency and choice in intimate life. In the intimate citizenship study, it had been our express intention to include as wide a range of socio-economic circumstances and educational backgrounds as possible, and to attempt to balance the sample in terms of class (an inherently fraught task in a cross-national project encompassing different welfare regimes and occupational structures), yet the final sample failed to achieve such a "balance." This too pointed towards the need to explore the relationship between patterns of economic and intimate life.

\section{Economic Citizenship and Intimate Life Amongst Elder Care Workers}

Our empirical research suggests that many recent accounts of the new and emerging inequalities between different categories of women (Esping-Andersen 2009; Glenn 1992; Rollins 1990) are somewhat over simplistic, notably because, in most national contexts, the fastest growth in demand for paid care services does not come from dual-earner households, but rather from the dependent elderly (Marbot 2009). In line with the hypothesis 
elaborated by the Italian economist Annamaria Simonazzi, our research found no universal pattern of "minoritized" workers being pushed into the elder care sector across national contexts (Lyon 2010; Saraceno and Keck 2010; Simonazzi 2008). Neither did we find evidence of elder care jobs being universally "deregulated" to the same extent. To assess the degree of "flexibilization" of elder care jobs, we used Beck's definition of the "two models of employment" that he claims now coexist under the conditions of "second modernity":

One is the welfare, post-war model of full-employment, characterized by very low unemployment, a male family wage-earner, normal, usually secure work contracts, the idea of a career for the middle classes, a job for life. The other model is what we could call fragile or flexible employment - which means flexitime, part-time work, short-term contracts, people juggling different types of work at the same time. This second category of fragile employment is increasing rapidly in developed countries worldwide (Beck 2000, 209).

Beck's first employment model could be said to encapsulate the "standard economic citizenship package" from which women were historically excluded (Le Feuvre et al. 2012), whereas the second model optimizes the reasons for women's lack of full economic citizenship, as analysed by Kessler-Harris (2001, 2003). However, as Simonazzi (2008) has suggested, the type of "employment contract" associated with elder care jobs varies significantly, both between countries and between the different care work niches in each national context. By engaging in a comparative analysis of the economic and intimate citizenship experiences of elder care workers, we are able to understand some of the complex entanglements of these two dimensions of citizenship in an increasingly multicultural European context. In the three countries studied here we found examples of elder care work being organized in dramatically different ways and we identified three distinct "types" of elder care jobs.

\section{The "Standard" Employment Model}

Many elder care jobs continue to be organized according to the "standard employment" model of the Fordist, "first modernity" (Beck 2000) era, offering highly regulated working and employment conditions, open-ended contracts, full or near full-time working hours, relatively generous levels of pay, financial compensation for unsocial hours, numerous possibilities for training and promotion, holiday pay entitlements, the collective representation of workers' interests through trade unions, etc. With few exceptions, the Norwegian case study exemplifies this employment model (Ervik 2010), as do a number of jobs in French elder care institutions (Le Feuvre, Metso, and Chaker 2010). Despite the recent introduction of external tendering of existing (and relatively comprehensive) public sector care services to private-for-profit or non-profit organizations, these elder care niches are characterized by high levels of public sector control over standards, including generous provisions for staff training 
as well as health and safety cover. In this case, elder care jobs often provide open access routes to other sectors of the labour market.

\section{The "Flexible" Employment Model}

In other cases, the elder care jobs we analysed were organized according to Beck's "flexible or fragile" employment model, offering low levels of pay, lowentry barriers, fixed-term, part-time contracts, irregular working hours, no compensation for unsocial hours, problematic access to statutory maternity leave or holiday pay, low levels of trade union membership, and limited health and safety provisions. In France, for example, recent policies to promote home-based as against institutionalized elder care services (Doniol-Shaw, Lada, and Dussuet 2007) have led to the rapid numerical increase (Agence nationale des services à la personne 2007; Dussuet 2009; Marquier 2010) in jobs offering such "flexible" employment contacts, the development of multiemployers and a blurring of the divide between professional elder care and domestic labour (Dussuet 2009; Fraisse 2009; Jany-Catrice 2010; Pennec 2002). Employment conditions are largely similar in the Polish elder care institutions, where even full-time jobs rarely provide a "living wage" (Krajewska 2010) and also in some marginalized care work niches (such as au-pairing) of the Nordic societies (Widding Isaksen 2010).

\section{The "Deregulated" Employment Model}

Finally, some elder care jobs were characterized by a complete lack of formalization or regulation. They were undeclared jobs, with no legal limits on working time, no welfare benefits, no health and safety regulations, no pension rights, no statutory maternity leave or holiday pay. The rapid development of undeclared home-based elder care services provided almost exclusively by migrant workers in Poland could be used to illustrate this "deregulated" employment model (Krajewska 2009).

We believe that this typology is useful, since it reveals that there is nothing intrinsic to elder care work that makes it impossible to regulate along the lines of the "standard economic citizenship package" (Le Feuvre et al. 2012). Contrary to the conclusions reached in much of the existing feminist literature on this topic, care work in general and elder care work in particular is not necessarily organized according to the principles of the "flexible" or "deregulated" employment models. In many countries this is the case, but it would be misleading to conclude that experiences of many elder care workers are determined by the nature and content of their work, rather than by the public's/ state's willingness (or lack of) to regulate market forces.

When we consider the intimate citizenship experiences of elder care workers, a clear relationship exists between the degree of autonomy and selfdetermination they can exercise with regard to their intimate living arrangements and the type of "employment contract" under which they carry out 
their work. Overall, the vast majority of the elder care workers in our study were either married, usually with children, or cohabiting; only a small minority of them were living outside a heterosexual couple/family configuration. However, the distribution of non-conventional living arrangements was far from random, and varied considerably from one national context to another.

So, what, more specifically, is to be learnt about the relationship between economic and intimate citizenship from this research? First, the recent growth in elder care jobs (Jenson and Jacobzone 2000) clearly reflects transformations in intimate and economic life, since many of the new employment opportunities result from the "externalization" of the caring tasks previously carried out unpaid by women in the family and which they are no longer willing/able to undertake, both due to their increased economic activity rates and to the transformation of traditional, largely heterosexual, family living arrangements. Secondly, labour market deregulation (at least in the case of elder care) is related to the "detraditionalization" of the way people live their intimate lives, but not necessarily in the ways one would expect from reading the "individualization theorists."

High levels of regulation and social protection of elder care work (as in the Norwegian case and, to a lesser extent, institutionalized elder care work services in France) offer the most conducive conditions for women to adopt an "adult worker" model of economic citizenship (and to be able thereby to maintain an autonomous household), but this does not seem to be systematically associated with the proliferation of non-conventional intimate living arrangements. On the other hand, relatively high levels of labour market flexibilization tend to be associated with the more traditional heterosexual "modified male breadwinner" or " 1.5 family worker" models, as in the institutionalized elder care jobs in Poland. Finally, the most deregulated forms of elder care (as in the case of undeclared or "grey" home-based, live-in care services in Poland and some sectors of the direct payment, home-based services in France) are associated with the highest levels of "detraditionalization" in living arrangements. However, despite the fact that the migrant care workers are almost always living as independent economic actors (not necessarily through choice), they are nevertheless deeply embedded in intergenerational care chains (Ehrenreich and Hochschild 2002) and tied to normative obligations to their extended family in their home country.

Thus, only a handful of the twenty-three Norwegian (two male and twentyone female) elder care workers we interviewed were living outside a conventional couple/family configuration. ${ }^{14}$ About half of our Norwegian interviewees were on full-time contracts, with only two (both migrants) working below 60 percent of a full-time job (Ervik 2010). None of the "nonconventional" Norwegian elder care workers were experiencing any particular economic hardship. Furthermore, none of those living in conventional households implied any relationship between their working lives and their intimate life choices. When the possibility of separation or divorce was mentioned, 
these intimate life events were not expected to have any impact on their future in the elder care sector.

This was also largely the case for the fifteen native French care workers, of whom only one (a forty-year-old female qualified home-help) was single and living alone. The others were all married or cohabiting, with or without children. In France too, about half (eleven of twenty-five) of the elder care workers were on full-time, open-ended contracts, although many had initially entered the elder care sector through (very) part-time and often temporary jobs, before gradually increasing their hours and improving their employment stability, sometimes over a very long period of time (fifteen to twenty years). ${ }^{15}$ This relatively high level of full-time employment (in a sector notorious for its reliance on part-time workers and fixed-term contracts) reflects the relatively large proportion of qualified elder care workers in our sample: almost all the female majority carers we interviewed in France had some kind of professional qualification specifically in elder care work.

Thus, despite their tendency to rather conventional living arrangements, we would suggest that these Norwegian and French elder carers could largely be characterized as autonomous "adult citizen workers," insofar as their economic citizenship experiences were disconnected from their intimate citizenship practices. The (in)stability of their living arrangements was seen as largely inconsequential for their employment-related aspirations, ambitions, and experiences. In other words, although those care workers whose working conditions came closest to the "standard employment model" were not all leading unconventional intimate lives, their emotional ties to their "intimate others" were not seen as a condition for their continued employment in elder care.

This particularly "disconnected" experience of economic and intimate citizenship stood in stark contrast to the accounts of those elder care workers whose working conditions were closest to a "flexible" employment model. This was clearly the case for all the majority/native women working in Polish elder care institutions. Again, this group was largely dominated by conventional heterosexual couple/family configurations: of the twenty-two Polish majority care workers above thirty years of age, fifteen were married, six were divorced, separated or widowed, and only one (a nun) was single (Krajewska 2010). The five elder care workers aged below thirty years were all single. However, in rather stark contrast to their Norwegian and French counterparts, these Polish care workers frequently stressed that they would have been (or, indeed, were) unable to "survive" in the institutional elder care jobs without the support of a main breadwinner, usually their husband, and sometimes adult children or parents. Furthermore, their moral commitment to elder care, in a country where there are strong normative beliefs concerning the "duty" of children to care for their dependent parents (Krajewska 2010), was largely framed with reference to a "1.5 earner family" model of gender relations. The stability of their own conventional intimate living arrangements was precisely what made it possible for them to care for the parents of people who, for 
various reasons, including their own economic emigration from Poland, were not in a position to do so. They took on this task despite the very low pay and limited benefits associated with jobs in elder care institutions and were able to do so precisely because they continued to receive some social benefits (notably pensions) through their status as wives (or daughters), rather than through their own jobs (Kessler-Harris 2001; Levine Frader 2008). In this case, turmoil in their intimate lives, particularly the loss or departure of a breadwinning spouse, could threaten their ability to continue providing paid elder care services. Unless the divorced and widowed elder care workers could find an alternative "main breadwinner" to rely on, their future within institutionalized elder care work was severely compromised. This was also the position expressed by the young, single female carers, for whom marriage represented a sine qua non condition for remaining employed in the elder care institutions beyond an age where they could legitimately depend on the financial support of their own parents.

Thus, although their objective intimate living arrangements barely differed from those of their Norwegian and French counterparts, the native Polish female carers experienced first-hand the entanglements of economic and intimate citizenship. The inherently "fragile" character of their employment conditions seemed to require conventional living arrangements and any changes to these had immediate consequences for their ability to continue providing the elder care services that they saw as so socially vital (but experienced as economically under-valued). In this case, the "individualization" of their economic citizenship experiences clearly mitigated possibilities of "detraditionalization" in the sphere of intimate life.

The migrant or minoritized elder care workers in France and Poland provided a third and final example of the varying forms of "entanglement" (or "disentanglement") of economic and intimate citizenship. These two groups included the highest number of care workers living outside the conventional couple/family configuration: only three or the fifteen migrant (Ukranian) care workers in Poland were married (Krajewska 2009) and only one of the thirteen minoritized (mostly North African) French interviewees was married/cohabiting with a man (Le Feuvre, Metso, and Chaker 2010). The differences cannot be explained by age or generational differences, since two-thirds of both subgroups were aged over thirty years at the time of the interviews. For many of these sub-groups of interviewees, the move into elder care work generally came after a dramatic change in intimate living arrangements. Following separation, divorce or severe health problems for their (male) partners, these women were obliged to take on a breadwinning role, which they had rarely expected to adopt in the course of their adult lives. Thus their non-conventional intimate living conditions were more a result of "biographical accident" than choice. Due to the reduction in the various welfare transfers that they would previously have expected to receive as dependent wives or single mothers, they were actively encouraged to ensure their own survival through employment, according 
to the "adult worker" model of economic citizenship. The prevalence of racial stereotypes about their inherent "caring capabilities" made it relatively easy for them to find home-based elder care jobs (Le Feuvre, Metso, and Chaker 2010). Their employment experiences left them struggling financially, and emotionally torn between providing an acceptable level of care to their elderly clients and continuing to service their own families' care needs, intermittently or from a distance (Ehrenreich and Hochschild 2002; Hochschild 2004). Whilst this group could be seen to combine the most deregulation forms of employment and the most "advanced" forms of detraditionalization in their living arrangements, it would be difficult to describe them as experiencing either full intimate or economic citizenship.

Thus, whilst the individualization theorists tend to see women's increased economic activity rates and the detraditionalization of intimate life as interrelated dimensions of the "individualization process", our research would seem to suggest that the relationship between these phenomena is more complex and potentially contradictory. We will return to these tensions after discussing the findings of the intimate citizenship project.

\section{Intimate Citizenship and Economic Life Outside the Conventional Couple and Family}

An early indication of the salience of our concern with the relationship between experiences of intimate and economic citizenship emerged during the fieldwork for the intimate citizenship project. We found ourselves facing considerable difficulties recruiting interviewees; it was a hard-to-reach sample, given the twin focus on people living outside conventional families and couples, and our desire, in line with FEMCIT's emphasis on the increasingly multicultural character of contemporary Europe, to strongly represent members of racialized/minoritized groups. ${ }^{16}$ Despite going to great ethnographic lengths, over extended periods of time in the field, to seek interviewees from a wide range of occupational and educational backgrounds, we ultimately ended up with a sample that was heavily skewed towards people who had completed higher education (forty of the sixty-seven), and that contained a considerably larger proportion of managerial and professional workers than the national populations at large. The sample was just over one-third managerial/ professional, just under one-third in intermediate occupations, and just under one-third was in routine/manual work and precarious positions (unemployed or in insecure self-employment). In the absence of robust cross-national quantitative data about the range of non-conventional patterns of intimate life that we studied and their distribution across socio-economic groupings, this "sampling effect" in itself points to the need for further research on the relationship between "individualized" forms of non-conventional intimate life and the educational capital and capacity to earn a decent independent income. ${ }^{17}$ 
Moving to the interview data itself, we analysed the lengthy biographical narratives offered to us by our interviewees, focusing on their subjective constructions and representations of their intimate life experiences. Across the data set we identified five main narratives of intimate citizenship, ranging from those that expressed a strong sense of intimate agency and relational autonomy to some that seemed to lack any such a sense. Our focus in what follows is on what we might learn about the relationship between these differentiated experiences of intimate citizenship and our interviewees' economic resources and positioning.

\section{Narratives of Self-Realization and Authenticity}

Nearly half our interviewees (thirty-one of sixty-seven) offered accounts that we understand primarily as narratives of self-realization and authenticity, in which the dominant theme was the process of "becoming oneself," in terms of the unfolding of self-identity and/or the development of intimate relationships. These narratives expressed a significant sense of individual agency and relational autonomy. They articulated a belief that the interviewee was in touch with their personal desires and spoke of the experience of achieving, finding or approaching what they desired in their intimate lives. These interviewees saw themselves as overcoming, or coming to terms with, the challenges and difficulties of intimate life that they had faced. As such they were the strongest narratives of intimate citizenship. Many of the narratives of self-realization and authenticity in relation to intimate life were accompanied by stories of fulfilment and achievement in the arena of paid work.

Narratives of self-realization were considerably more prevalent amongst the women interviewees than amongst the men, and they were the predominant narrative amongst Norwegian interviewees-twelve of seventeen interviewees - with slightly fewer than half of the UK and Portuguese interviewees offering such narratives. They were least common amongst the Bulgarian interviewees.

It is striking to note that narratives of self-realization were associated with experiences of higher education and with employment in higher socioeconomic groups: twenty-three of the forty interviewees who had completed undergraduate education offered us narratives of self-realization, compared with only two of the twelve educated to the age of sixteen or younger, and six of fifteen who had completed secondary school. Amongst women interviewees, narratives of self-realization and authenticity were also disproportionately heard from those in managerial/professional occupations: such narratives were offered by nine of the twelve women and by four of the five men in managerial/professional work. This resonates with the arguments of social scientists who have linked the rise of late modern narratives of self-realization - the "reflexive project of self" (Giddens 1992), and the desire to lead a "life of one's own" (Beck and Beck-Gernsheim 2002) — with the processes of socioeconomic transformation that are associated with the growth of welfare states, 
increased access to higher education, the rise of the service class, and the spreading of "post-material” values (Inglehart 1977, 1997).

\section{Narratives of Oppression}

At the other end of the spectrum of experiences of intimate citizenship were the narratives of oppression offered to us by four interviewees. In these narratives, interviewees recounted experiences of grave restriction of their intimate life choices and/or violation of their bodily integrity, self and/or intimate relationships, without offering an account of resistance, and without any real challenge to, or questioning of, their intimate life conditions and experiences. These were narratives of people whom it would be difficult to describe as "intimate citizens."

Narratives of oppression were all told to us by Roma women interviewees, three of whom were Bulgarian and one Portuguese. They had all been educated to the age of sixteen or less, and one was unable to read or write. Two were unemployed, one was irregularly self-employed, selling flowers and one was in a routine/manual occupation. In the stories of these interviewees, material hardship, poverty, poor housing, and social exclusion were fundamentally intertwined with their descriptions of the oppressions they faced in their intimate lives.

\section{Narratives of Struggle}

Thirteen interviewees offered us narratives in which the dominant story was of struggle, resistance, and/or challenge to relations of oppression, restriction, or dependence in intimate life. The struggles narrated were variously experiences as internal/psychic, emotional, interpersonal, and occasionally political, taking the form of an articulation of a critique of established gender relations and intimate normativities.

These narratives were similarly prevalent amongst Bulgarian, Norwegian, and Portuguese interviewees, with two of each thus categorized, and six UK interviewees offered us such stories. In terms of education and occupation, the interviewees offering narratives of struggle were less clearly concentrated in particular locations, although there was a relative absence of those in routine/ manual work and in the most precarious economic positions, and with the lowest levels of education, which might point to a certain fatalism about intimate life possibilities and a lack of a sense of agency amongst these groups.

\section{Narratives of Un-fulfilment or Failure}

Eleven interviewees offered narratives in which the dominant theme in relation to intimate citizenship was one of unfulfilment or failure, of not achieving what is expected or desired in their intimate life; some of these narratives were tempered by a recognition that this unfulfilment or failure might pass and prove to be temporary: eight of twenty-six men in the sample offered such stories, compared with only three of forty-one women. These stories were 
more common amongst those with less education-four of the twelve interviewees who were educated to sixteen or less, and three of the fifteen who had completed secondary school, as opposed to only four of the forty who had been educated to undergraduate level told such stories. In terms of occupation, the men were distributed across the occupational spectrum-three were in managerial/professional employment, two in intermediate, one in routine/ manual work and two were self-employed; two of the women were in routine/ manual work and one was unemployed.

\section{Conventional Narratives}

Finally, we identified eight cases where the dominant narrative was a "conventional" or normative, narrative of intimate life; that is, a narrative that speaks, in an uncritical way, about the interviewee's unproblematic experience of intimate citizenship as following expected patterns and conventional norms. All the conventional narratives were offered by men, four of whom were Bulgarian, three Portuguese, and one from the UK, with none from our Norwegian interviewees. These narratives were distributed fairly evenly across the range of educational levels - with five of our forty undergraduate educated interviewees offering such stories, two of the fifteen who had completed secondary school, and one of the twelve who had been educated to the age of sixteen or less. These men were clustered in intermediate occupations and routine/manual and precarious employment.

It is clear from this analysis that the sort of subjective orientation to intimate life described as characteristic of late modernity by the individualization theorists is strongly represented amongst our sample of "non-conventionals." However, it is also notable that the narratives of self-realization and authenticity are concentrated amongst the more highly educated, and those who are also experiencing fuller economic citizenship.

To focus on the most striking findings about the relationship between intimate citizenship and economic citizenship, we can look at those who are in the weakest positions in terms of economic citizenship—-with the lowest levels of education (left school at sixteen or less) and occupying the lowest and most precarious socio-economic positions. Here we find that very few offered us the strongest narratives of intimate citizenship-the narratives of self-realization and authenticity. Moreover, all the narratives of oppression in the sample were to be found amongst those who left school before the age of sixteen, and all were, in fact, Roma women. Compare this with the narratives of those in the strongest positions in terms of economic citizenship, where we find a preponderance of narratives of self-realization and authenticity amongst those who have completed higher education — of the forty, twenty-three offered narratives of self-realization and authenticity, eight narratives of struggle, four narratives of unfulfilment or failure, and five conventional narratives; there were no narratives of oppression. When it comes to occupation, there were over twice as 
many narratives of self-realization and authenticity amongst the managers and professionals as amongst those from the lowest and most precarious socioeconomic groups.

Looking at the two extremes of our interviewees' intimate citizenship narratives cross-nationally, it is striking that Norway is where we found by far the largest number of narratives of self-realization and authenticity. It is, we would suggest, no coincidence that it is Norway, the "woman-friendly" (Hernes 1987) social democratic welfare state, that has strongest integration of feminist and lesbian and gay movement intimate citizenship claims into law and policy (Roseneil et al. 2011, 2013), the most objectively individualized patterns of intimate life (having, for instance the highest level of one person households), and by far the highest GDP of the four countries we studied. ${ }^{18}$ Slightly fewer than half of the UK and Portuguese interviewees offered narratives of selfrealization and authenticity, and they were least common among the more economically precarious Bulgarians, where GDP is less than a quarter of Norway, and social movement claims around intimate citizenship have been less powerfully articulated and translated into law and policy (Roseneil et al. 2011, 2013). Narratives of oppression were to be found primarily amongst the Bulgarian interviewees and were all offered by Roma women.

The Roma "non-conventionals" we interviewed were the most precariously positioned sub-group in our sample-only one person, a man, was educated beyond the age of sixteen, and only one was not in the lowest and most precarious socio-economic group. The Roma interviewees' economic and social precarity was vividly expressed in the life stories they told us, none of which spoke in the language of self-realization and authenticity. With the exception of one conventional story and one narrative of struggle, they were divided between narratives of oppression — which expressed almost no agency—and narratives of unfulfilment or failure. It was clearest in the stories of our Roma interviewees how interconnected experiences of gendered and racialized suffering in intimate life and deprivation in economic life are-particularly how important the lack of the capacity to earn an adequate independent living is for Roma women. There were numerous accounts of racialized discrimination, hostility, and prejudice in schooling and later life that impacted on their capacities as economic actors and that in turn meant that leaving violent and abusive relationships was extremely difficult. Equally, the traditional gendered experience of being "stolen"/"running away"19 at an early age, and thereby marrying according to Roma custom, served to end young women's education, and had a life-long impact on their experiences of intimate citizenship and their potential access to economic citizenship.

To pursue the comparison between Bulgaria and Norway with reference to sexuality, whilst lesbians and gay men in both countries spoke of the personal, psychic struggles they faced in coming to terms with their sexual desires and about the cultural heteronormativities they encountered in their social worlds, there were real material differences in their experiences of living openly non- 
heterosexual intimate lives. No lesbians or gay men in Norway talked about the sort of severe economic restrictions imposed on their agency as intimate citizens described by Bulgarian interviewees, such as the lesbian who lacked private domestic space for intimacy and sex with her partner, because she could not afford to leave the parental home, and the gay men for whom sex work seemed to be the only way of earning a living, or who narrowly avoided being trafficked to a more prosperous European country to work in a gay sauna.

\section{Conclusions}

So what do the findings of these research projects enable us to say about the entanglements of economic and intimate citizenship in contemporary Europe? In bringing the findings of these projects into dialogue, we became interested in the paradoxes of the individualization process (Beck and Beck-Gernsheim 1995).

The evidence from our FEMCIT research would seem to suggest that the two distinct and highly gendered processes discussed by social theorists of individualization - the flexibilization of labour markets and the detraditionalization of intimate life - can be identified empirically, but that they do not sit comfortably together and, indeed, that there are inherent tensions between the development of what Beck calls the "flexible" employment model and the ability of individuals to live a "life of one's own" in the sphere of intimate relationships.

We wish to underline that we are not saying that economic citizenship and intimate citizenship map straightforwardly onto each other, or that economic resources alone can predict the degree of self-determination in intimacy; we do not wish to resurrect a Marxist notion of ultimate determination by economic forces. The intimate citizenship project interviews were replete with accounts of less than full intimate citizenship across the spectrum of educational backgrounds and occupational groups-of oppressive, discriminatory, or marginalizing experiences that impinged upon or violated our interviewees' integrity and personhood as gendered intimate citizens (see Roseneil et al. 2012). Likewise, the economic citizenship interviews contained tales of determination and courage in the realization of aspirations for a non-conventional intimate life, despite the precarious nature of the elder care jobs on offer in a particular national or local context.

But, that said, our research does suggest that it is difficult to flourish as an intimate citizen - to experience a sense of agency and choice, to be able to exercise relational autonomy and self-determination in intimate life-without enjoying a degree of economic autonomy. Subjective experiences of intimate citizenship appear to be considerably more positive amongst those with higher education and those further up the occupational hierarchy, as well as in the 
richer countries and those with more regulated labour markets. Our research would thus seem to suggest that the new emphasis placed on the inclusion of women in the "adult worker" model of citizenship ${ }^{20}$ alongside the simultaneous deregulation of large sectors of the European labour market (particularly the most highly feminized, as is evident in elder care) may hamper rather than foster the "detraditionalization" of intimate life. Contrary to any idea of the inexorable advance of individualization processes, the "renewed jointism" (Daly $2011,16)$ that is enacted by policies aimed at promoting the widespread adoption of the "adult worker model" fails to accommodate and support individuals (particularly women) living outside the couple form. As long as they are in a position to command access to sufficient autonomous economic resources, individuals may indeed be in a position to adopt independent or non-conventional living arrangements and to experience these in terms of selfrealization and authenticity. However, in many countries, women working in the most "flexible" or deregulated sectors of the elder care labour market are faced with what might seem like the material impossibility of surviving beyond the couple frame. Our studies also point to the particular additional vulnerabilities and suffering that face some of those who are living individualized intimate lives outside heterosexual partnerships, but who have not achieved the hallowed status of "adult citizen worker", and who do not have access to the resources of the ideal reflexive, self-realizing citizen of late modernity (Ehrenberg 2010). Contrary to the expectations of those who would see processes of individualization as proceeding untrammelled across contemporary Europe, the reconfiguration of work and welfare is clearly failing to deliver the freedom from "status fate," "traditional commitments and support relationships" (Beck 2002, 202-203) that women could legitimately expect to reap, in exchange for their increased confrontation with the "constraints of existence in the labour market" (Beck 2002, 203).

Whilst we do not endorse what might be seen as the "patriarchal pessimism" (Roseneil 2007) of one leading theorist of individualization- Zygmunt Bauman (2003)—who often seems to express nostalgia for the days of secure male employment and traditional families, our research does support Bauman's identification of "the main contradiction" of the age of individualization: "the yawning gap between the right of self-assertion and the capacity to control the social settings which render such self-assertion feasible or unrealistic" (Bauman 2002, xix).

However, our research also highlights how particular welfare regimes might mitigate this contradiction. Contrary to Beck's affirmation that the nation state no longer represents the most effective site of political action (or, indeed, the most pertinent object of sociological enquiry) (Beck 2000), our research serves to underline that societal-level political choices and policies can intervene to alter the (dis)entanglements of economic and intimate citizenship, even under conditions of globalization and the diffusion of "activation" objectives in European social policy. If, as social scientists, we wish to develop better 
understandings of contemporary conditions and experiences of citizenship, we need to attend both to the distinctive and irreducible concepts of economic and intimate citizenship and to their complex, potentially contradictory entanglements and processes of co-production. But we also need to remember the difference that social citizenship-national or local level social welfare policies - can make in shaping processes of individualization and the contours of gender (in)equality in economic and intimate life. As Bauman says: "through trial and error, critical reflection and bold experimentation, we must learn to tackle [this contradiction] collectively" (Bauman 2002, xix). As economic crisis and the politics of austerity grip Europe, this task presents a huge feminist challenge for the future.

\section{Notes}

Nicky Le Feuvre is Professor of Sociology of Work Director of the Institute of Social Sciences at the University of Lausanne. She is also a member of the Steering Board of the Swiss National Centre of Competence in Research LIVES (Overcoming Vulnerability: Life Course Perspectives). Her main research interests relate to the changes taking place in the sexual division of paid and unpaid work in the contemporary European context, and address issues such as: the feminization of professional and managerial occupations, the expansion of employment in the elder care sector, and gender inequalities amongst "seniors" in employment. She has also carried out several studies on the institutionalization of gender studies in European universities and on the implementation of equal opportunity policies in France and the UK. Her publications include: Exploring Women's Academic Careers in Cross-National Perspective: Lessons for Equal Opportunity Policies, Equal Opportunities International, $\mathrm{Vol} 28, \mathrm{n}^{\circ} 1: 9-23,2009$; Le sexe de la mondialisation: Genre, classe, race et nouvelle division du travail (ed. with J. Falquet, H. Hirata, D. Kergoat, B. Labari and F. Sow, F. Editions de Sciences Po, 2010).

Sasha Roseneil is Professor of Sociology and Social Theory and Director of the Birkbeck Institute for Social Research at Birkbeck College, University of London. She is also Professor II in Sociology at the Centre for Gender Research at the University of Oslo. She is the author of Disarming Patriarchy (1995, Open University Press), and Common Women, Uncommon Practices: The Queer Feminisms of Greenham (2000, Cassell). She is editor or co-editor of Stirring It: Challenges for Feminism (1994, Taylor and Francis), Practising Identities (1999, Macmillan), Consuming Cultures (1999, Macmillan), Globalization and Social Movements (2000, Palgrave), and special issues of Citizenship Studies (2000, 2013), Feminist Theory (2001, 2003), Current Sociology (2004), Social Politics (2004), and Women's Studies International Forum (2013). Her latest books are Social Research after the Cultural Turn (ed. with Stephen Frosh, Palgrave, 2012), Remaking Citizenship in Multicultural Europe: Women's Movements, Gender and Diversity (ed. with Beatrice Halsaa and Sevil Sumer, Palgrave, 2012) and Beyond Citizenship: Feminism and the Transformation of Belonging (Palgrave, 2013).

1. FEMCIT-Gendered Citizenship in Multicultural Europe: the impact of contemporary women's movements-was a European Union 6th Framework 
Integrated Project, directed by Beatrice Halsaa, Solveig Bergman Sasha Roseneil, and Sevil Sümer, that ran from 2007 to 2011 (project number: 028746). See Halsaa, Roseneil, and Sümer $(2011,2012)$ and www.femcit.org.

2. This project was led by Nicky Le Feuvre, in collaboration with Saloua Chaker, Rune Ervik, Anna Krajewska, and Milka Metso.

3. This project was led by Sasha Roseneil, in collaboration with Isabel Crowhurst, Tone Hellesund, Ana Cristina Santos, and Mariya Stoilova.

4. The seven demands were: 1. Equal Pay 2. Equal Educational and Job Opportunities 3. Free Contraception and Abortion on Demand 4. Free 24-hour Nurseries 5. Legal and Financial Independence for All Women 6. The Right to a Self-Defined Sexuality - An End to Discrimination Against Lesbians 7. Freedom for all women from intimidation by the threat or use of violence or sexual coercion regardless of marital status; and an end to the laws, assumptions, and institutions which perpetuate male dominance and aggression to women.

5. There are, of course, some notable exceptions to this "couple-centred" vision of contemporary citizenship. Ann Orloff (1993, 2002) and Ruth Lister (1997) have, importantly, emphasized that women's ability to maintain an autonomous household should be regarded as central to their access to full citizenship.

6. The intimate citizenship project was also hampered by the lack of detailed agedifferentiated, comparable, and up-to-date data on non-conventional intimate living arrangements.

7. Alongside a burgeoning sociological literature on one-person households (e.g. Jamieson, Wasoff, and Simpson 2009; Wasoff, Jamieson, and Smith 2005), singleness and solo-living (Reynolds 2008; Trimberger 2005), recent work on "living apart together" relationships has drawn attention to this hitherto unrecognized mode of intimacy (Levin 2004), and to the challenges it poses to welfare theory and welfare provision that assume co-residence between intimate partners (Duncan et al. 2012; Roseneil 2006; Roseneil and Budgeon 2004).

8. In the humanities, Berlant $(1997,2000)$ has developed a parallel body of work exploring the affective attachments and politics of citizenship, nation and "the intimate public sphere."

9. We have chosen to work with the notion of intimate citizenship in preference to the narrower, but more widely used, concept of sexual citizenship (see, for example, Bell and Binnie 2000; Cossman 2007; Evans 1993; Richardson 2000; Weeks 1998).

10. See Roseneil et al. (2012) for a discussion of the methodology of the intimate citizenship project and Roseneil (2012) on the use of the biographical narrative interpretive method (BNIM).

11. Both projects also faced difficulties in meeting the desired sampling criteria. Men from majority ethnic groups proved to be particularly difficult to locate in the elder care sector in most countries (indeed, we did not manage to find any male workers in elder care institutions in Poland), and members of minoritized/racialized groups (Roma, Cape Verdean, Pakistani, Sami, and Turkish) living outside conventional families posed the greatest challenge to the intimate citizenship project. Nonetheless, forty-one of the sixty-seven intimate citizenship interviewees were members of minoritized/racialized groups. 
12. On the differences between life-history methods and the biographicalnarrative interpretive method, see Roseneil (2012) and Russell (2012).

13. This difference in emphasis might be seen as rather problematically reproducing the powerful gendered cultural association of the economic realm with the objective and rational, and the intimate realm with the subjective and emotional that this paper seeks to destabilize. We can only acknowledge this, and note the methodological challenge thus posed for future research on the relationship between economic circumstances and intimacy.

14. One Norwegian-born female nurse was single and living alone; one Thai migrant male care assistant, with a university degree in physics, was living with his child and two of his brothers and sisters; and two older Norwegian-born care workers, aged fifty-nine and sixty-one years old respectively (one working in a private nursing home and one in a municipal homecare service), were divorced, with non-cohabiting grown-up adult children.

15. The male care workers did not seem to benefit from better employment conditions then their female counterparts, since only one of our five male respondents was in a stable, full-time job at the time of the interview.

16. For a detailed discussion of how we tackled recruiting our "hard-to-reach" sample, see Crowhurst et al. (2013).

17. There is a small but growing literature that examines the economic lives of lesbians and/or gay men in the UK (Dunne 1997) and the United States (e.g. Albelda et al. 2009; Badgett 2001; Black, Sanders, and Taylor 2007), but an absence of such research in the other countries in our study; national statistics and surveys still rarely capture data about sexual orientation/identification, and have only recently started gathering data about same-sex partnerships. Overall, Albelda et al's secondary analysis of US data finds that "poverty is at least as common in the LGB population as among heterosexual people and their families" (2009, i). Black, Sanders, and Taylor's (2007) analysis of the 2000 US census suggests that partnered lesbians and gay men are better educated, and less likely to have a stay-at-home-partner (i.e. are less market specialised) than partnered heterosexuals. Albelda et al. (2009) find that higher educational attainment mitigates rates of poverty amongst partnered lesbians, gay men and bisexuals, with a particularly strong effect for lesbian couples: poverty rates amongst lesbian couples with a bachelor's degree or higher are below those for gay male couples and heterosexual married couples, whilst poverty rates for lesbian couples who have associate degrees or less are roughly double those of gay male and heterosexual married couples.

18. In 2011 one person households as a proportion of total households were: Norway 38\%; UK 30\%; Bulgaria 23\%; Portugal 17\% http://www.oecd.org/els/ family/ (accessed 28 May 2014). In 2012 GDP per capita was: Norway 195; UK 106; Portugal 76; Bulgaria 47. http://epp.eurostat.ec.europa.eu/statistics_explained/ index.php/GDP_per_capita,_consumption_per_capita_and_price_level_indices (accessed 28 May 2014).

19. A Roma custom (described as being "stolen" by our Bulgarian interviewees and as "running away" by the Portuguese) in which, at around the age of puberty, Roma girls have their first experience of sex with a Roma boy, after which they are considered married. 
20. Even when this takes the form of what Claire Annesley (2007) calls a "supported adult worker model" of welfare state, in contrast to the "unsupported neoliberal adult worker model" that she claims has emerged in the United States.

\section{References}

Adam, B. 1995. The rise of a gay and lesbian movement. New York: Twayne.

Agence nationale des services à la personne, A. 2007. Rapport annnuel 2007. Paris: ANSP.

Albelda, R., M. V. L. Badgett, A. Schneebaum, and G. J. Gates. 2009. Poverty in the lesbian, gay and bisexual community. The Williams Institute. http://williamsinstitute.law. ucla.edu/wp-content/uploads/Albelda-Badgett-Schneebaum-Gates-LGB-PovertyReport-March-2009.pdf (accessed 22 January 2014).

Annesley, C. 2007. Lisbon and social Europe: Towards a European 'Adult worker model' welfare system. Journal of European Social Policy, 17 (3): 195-205.

Badgett, M. V. L. 2001. Money, myths and change: The economic lives of lesbians and gay men. Chicago: Chicago University Press.

Bauman, Z. 2002. Forward: Individually, together. In Individualization: Institutionalized individualism and its social and political consequences, ed. U. Beck, and E. BeckGernsheim, xiv-xx. London: Sage.

. 2003. Liquid love: On the frailty of human bonds. Cambridge: Polity.

Bech, H. 1997. When men meet: Homosexuality and modernity. Cambridge: Polity.

Beck, U. 2000. The brave new world of work. Cambridge: Polity.

2002. Zombie Categories. In Individualization: Institutionalized individualism and its social and political consequences, ed. U. Beck, and E. Beck-Gernsheim, 202-12. London: Sage.

Beck, U., and E. Beck-Gernsheim. 1995. The normal chaos of love. Cambridge: Polity. . eds. 2002. Individualization, institutionalized individualism and its social and political consequences. London: Sage.

Bedford, K., and J. Jakobsen. 2009. Sexual and economic justice. Volume 4 New Feminist Solutions. New York: Barnard Center for Research on Women. Available online http://bcrw.barnard.edu/publications/towards-a-vision-of-sexual-and-economicjustice/ (accessed 22 January 2014).

Bell, D., and J. Binnie. 2000. The sexual citizen: Queer politics and beyond. Cambridge: Polity.

Berlant, L. 1997. The queen of America goes to Washington city. Essays on sex and citizenship. Durham and London: Duke University Press.

Berlant, L., ed. 2000. Intimacy. Chicago: University of Chicago Press.

Black, D. A., S. G. Sanders, and L. Taylor. 2007. The economics of lesbian and gay families. Journal of Economic Perspectives, 21 (2): 53-70.

Bonoli, G. 2005. The politics of the new social policies: Providing coverage against new social risks in mature welfare states. Policy \& Politics, 33 (3): 431-9.

Butler, J. 1869. Women's work and women's culture. London: Macmillan. . 1998. Merely cultural. New Left Review, 227: 33-44.

Castel, R. 1995. Les métamorphoses de la question sociale: Une chronique du salariat. Paris: Fayard. 
Cossman, B. 2007. Sexual citizens: The legal and cultural regulations of sex and belonging. Stanford: Stanford University Press.

Crompton, R. 2006. Employment and the family: The reconfiguration of work and the family in contemporary societies. Cambridge: Cambridge University Press.

Crompton, R., S. Lewis, and C. Lyonette, eds. 2007. Women, men, work and family in Europe. Basingstoke: Palgrave Macmillan.

Crowhurst, I., S. Roseneil, T. Hellesund, A. C. Santos, and M. Stoilova. 2013. Close encounters: Researching intimate lives in Europe. International Journal of Social Research Methodology, 16 (6): 525-33.

Dahl, T. S. 1987. Women's law: An introduction to feminist jurisprudence. Oslo: Norwegian University Press.

Daly, M. 1994. Comparing welfare states: Towards a gender friendly approach. In Gendering welfare states, ed. D. Sainsbury, 101-17. London: Sage.

- 2011. What adult worker model? A critical look at recent social policy reform in europe from a gender and family perspective. Social Politics, 18 (1): 1-23.

Daly, M., and K. Rake. 2003. Gender and the welfare state: Care, work and welfare in Europe and the USA. Cambridge: Polity.

Delphy, C. 1970. L’Ennemi principal. Partisans, Numéro Spécial “Libération des Femmes, Années Zéro", 27: 157-72.

D'Emilio, J. 1983. Sexual politics, sexual communities: The making of a homosexual minority in the United States (1940-1970). Chicago, IL: University of Chicago Press.

de Singly, F. 1987. Fortune et infortune de la femme mariée: Sociologie de la ve conjugale. Paris: Presses universitaires de France.

. 2000. Libres ensemble. Paris: Nathan.

Doniol-Shaw, G., E. Lada, and A. Dussuet. 2007. Les parcours professionnels des femmes dans les métiers d'aide à la personne. Léviers et freins à la qualification et à la promotion. Paris: LATTS-CNRS (UMR 8134) Université Paris-Est.

Duncan, S., J. Carter, M. Phillips, S. Roseneil, and M. Stoilova. 2012. Legal rights for people who live apart together? Journal of Social Welfare and Family Law, 34 (4): 443-58.

Duncan, S., and R. Edwards, eds. 1997. Single mothers in an international context: Mothers or workers? London: UCL Press. Macmillan.

Dunne, G. A. 1997. Lesbian lifestyles: Women's work and the politics of sexuality. Basingstoke: Macmillan.

Dussuet, A. 2009. De la 'proximité' aux 'services à la personne': Le 'privé' comme facteur d'inégalité entre les hommes et les femmes. Economie et Société, 1: 123-44.

Ehrenberg, A. 2010. The weariness of the self: Diagnosing the history of depression in the contemporary age. Quebec: McGill-Queen's University Press.

Ehrenreich, B., and A. R. Hochschild, eds. 2002. Global women: Nannies, maids and sex workers in the new economy. London: Granta Books.

Ervik, R. 2010. Elderly care and economic citizenship in Norway: Traditional and emerging forms of employment in the elderly care sector and their impact on majoritized and minoritized carers. Bergan: Rokkan Centre, FEMCIT WP3 Report.

Esping-Andersen, G. 1990. The three worlds of welfare capitalism. Cambridge: Polity. Polity. 
Evans, D. 1993. Sexual citizenship: The material construction of sexualities. London: Routledge.

Fraisse, G. 2009. Service ou servitude: Essai sur les femmes toutes mains. Paris: Le Bord de l'eau éditions.

Fraser, N. 1994. After the family wage: Gender equity and the welfare state. Political Theory, 22 (4): 591-618.

- 1998. Heterosexism, misrecognition, and capitalism: A response. New Left Review, 228: 140-9.

2000. After the family wage: A postindustrial thought experiment. In Gender and citizenship in transition, ed. B. Hobson, 1-32. Basingstoke: Macmillan.

Friedman, M. 2005. Women and citizenship. Oxford: Oxford University Press.

Giddens, A. 1992. The transformation of intimacy: Sexuality, love and eroticism in modern societies. London: Polity.

- 1994. Living in a post-traditional society. In Reflexive moderniziation: Politics, tradition and aesthetics in the modern social order, ed. U. Beck, A. Giddens, and S. Lash, 56-109. Cambridge: Polity.

Glenn, N. E. 1992. From servitude to service work: Historical continuities in the racial division of reproductive work. Signs, 18 (1): 1-43.

Guillaumin, C. 1992. Sexe, race et pratique du pouvoir : L'idée de Nature. Paris: Côté-Femmes.

Halsaa, B., S. Roseneil, and S. Sümer, eds. 2011. FEMCIT: Gendered citizenship in multicultural Europe: The impact of contemporary women's movements. Work Package 7, Working Paper No. 5. Bergen: University of Bergen/Uni Rokkan Centre. http://www.femcit.org/files/FEMCIT\%20Final\%20Report\%20Published.pdf

- eds. 2012. Remaking citizenship in multicultural Europe: Women's movements, gender and diversity. Basingstoke: Palgrave Macmillan.

Heaphy, B. 2011. Gay identities and the culture of class. Sexualities, 14 (1): 42-62.

Heelas, P., S. Lash, and P. Morris, eds. 1996. Detraditionalization. Cambridge, MA: Oxford: Blackwell.

Hennessy, R. 2000. Profit and pleasure: Sexual identities in late capitalism. London and New York: Routledge.

Hernes, H. M. 1987. Welfare state and political power: Essays in state feminism. Oslo: Norwegian University Press.

Hobson, B. 2000. Economic citizenship: Reflections through the european policy mirror. In Gender and citizenship in transition, ed. B. Hobson, 84-117. Basingstoke: Macmillan.

Hochschild, A. 2004. Le nouvel or du monde. Nouvelles Questions Féministes, 23 (3): 59-74.

Inglehart, R. 1977. The silent revolution: Changing values and political styles among western publics. Princeton, NJ: Princeton University Press.

- 1997. Modernization and postmodernization: Cultural, economic and political change in 43 countries. Princeton, NJ: Princeton University Press.

Jamieson, L., F. Wasoff, and R. Simpson. 2009. Solo-living, demographic and family change: The need to know more about men. Sociological Research Online, 14. http://www.socresonline.org.uk/14/2/5.html

Jany-Catrice, F. 2010. La construction sociale du 'secteur' des services à la personne: Une banalisation programmée? Sociologie du Travail, 52: 521-37. 
Jenson, J. 2010. Diffusing ideas after neo-liberalism: The social investment perspective in Europe and Latin America. Global Social Policy, 10 (1): 59-84.

Jenson, J., and S. Jacobzone. 2000. Care allowances for the frail elderly and their impact on women care givers. Paris: OECD Labour Market and Social Policy Occasional Papers No. 41.

Kessler-Harris, A. 2001. In pursuit of equity: Women, men and the quest for economic citizenship in twentieth century America. New York: Oxford University Press.

. 2003. In pursuit of economic citizenship. Social Politics, 10 (2): 157-75.

Krajewska, A. 2009. Immigrant workers in the elderly care sector. Warsaw University: FEMCIT WP3 Report.

2010. Institutionalised elderly care in poland: Legal frameworks and real life practice. Warsaw University: FEMCIT WP3 Report.

Le Feuvre, N. 1999. Gender, occupational feminization and reflexivity: A cross-national perspective. In Restructuring gender relations and employment: The decline of the male breadwinner, ed. R. Crompton, 150-78. Oxford: Oxford University Press.

Le Feuvre, N., M. Metso, and S. Chaker. 2010. The economic citizenship experiences of elderly care workers in France. Toulouse: FEMCIT WP3 Report.

Le Feuvre, N., R. Ervik, A. Krajewska, and M Metso. 2012. Remaking economic citizenship in multicultural Europe: Women's movements claims and the 'commodification of care' in comparative perspective. In Remaking citizenship in multicultural Europe: Women's movements, gender and diversity, ed. B. Halsaa, S. Roseneil, and S. Sümer, 70-93. Basingstoke: Palgrave Macmillan.

Leonard, D., and S. Allen, eds. 1991. Sexual divisions revisited. New York: St. Martin's Press.

Levin, I. 2004. Living apart together: A new family form. Current Sociology, 52: 223-40.

Levine Frader, L. 2008. Breadwinners and citizens: Gender in the making of the French social model. Durham: Duke University Press.

Lewis, J. 1992. Gender and the development of welfare regimes. Journal of European Social Policy, 2 (3): 159-73.

Lewis, J., ed. 1997. Lone mothers in European welfare state regimes: Shifting policy logics. London: Jessica Kingsley.

Lewis, J., and S Guillari. 2005. The adult worker model, family, gender equality and care: the search for new policy principles and the possibilities and problems of the capabilities approach. Economy and Society, 34 (1): 76-104.

Lister, R. 1997. Citizenship: Feminist perspectives. London: Macmillan.

Lister, R., F. Williams, A. Antonnen, M. Bussemaker, U. Gerhaud, S. Johansson, J. Heinen, A. Leira, B. Siim, and C. Tobio. 2007. Gendering citizenship in Western Europe: New challenges for citizenship research in a cross-national perspective. Bristol: Policy Press.

Lyon, D. 2010. Intersections and boundaries of work and non work: The case of eldercare in comparative European perspective. European Societies, 12 (2): 163-85.

Mackenzie, C., and N. Stoljar, eds. 2000. Relational autonomy: Feminist perspectives on autonomy, agency and the social self. Oxford and New York: Oxford University Press.

Magnoni-d'Intagnano, B. 1999. Egalité entre hommes et femmes: Aspects économiques. Paris: La Documentation Française.

Marbot, C. 2009. Le recours aux services à domicile et ses déterminants en france: Une analyse au coeur du ménage. Travail, Genre et Sociétés, 22 (2): 31-52. 
Marquier, R. 2010. Les intervenantes au domicile des personnes fragilisées en 2008. Etudes \& Résultats, 728: 1-8.

Marshall, T. H. 1950. Citizenship and social class and other essays. Cambridge: Cambridge University Press.

Méda, D. 2010. Travail: La révolution nécessaire. Paris: Editions de l'Aube.

Metso, M., N. Le Feuvre, A.-J. Berg, and A. Krajewska, eds. 2009. Mapping economic citizenship issues from women's movement publications in Finland, France, Norway, Poland and the UK. FEMCIT WP3, Working Paper 2. http://www.femcit. org/files/WP3_WorkingpaperNo2.pdf

Mitchell, J. 1966. Women: The longest revolution. New Left Review, (40): 11-37.

Morton, D., ed. 1996. The material queer. Boulder, CO: Westview.

OECD. 2006. Men and women in OECD countries. Paris: OECD.

Offen, K. 2000. European feminisms 1700-1950. A political history. Stanford: Stanford University Press.

Orloff, A. S. 1993. Gender and the social rights of citizenship: State policies and gender relations in comparative research. American Sociological Review, 58 (3): 303-28.

Orloff, A. S. 2002. Women's employment and welfare regimes. New York: United Nations Research Institute for Social Development.

Pankhurst, C. 1913. The scourge and how to end it. London: The Woman's Press.

Pennec, S. 2002. Les politiques envers les personnes âgées dépendantes: Providence des femmes ou assignation à domicile? Lien Social et Politique, 47: 129-42.

Pettman, J. 1999. Globalization and the gendered politics of citizenship. In Women, citizenship and difference, ed. N. Yuval-Davis, and P. Werbner. London: Zed Books.

Pfau-Effinger, B., and B. Geissler, eds. 2005. Care arrangements and social integration in european societies. Berlin: Policy Press.

Plummer, K. 1995. Telling sexual stories: Power, change and social worlds. London: Routledge.

- 2003. Intimate citizenship: Private discussions and public dialogues. Seattle, WA and London: University of Washington Press.

Prince Cooke, L., and J. Baxter. 2010. 'Families' in international context: Comparing institutional effects across western societies. Journal of Marriage and Family, 72: 516-36.

Reynolds, J. 2008. The single woman: A discursive investigation. London: Routledge.

Richardson, D. 2000. Constructing sexual citizenship: Theorizing sexual rights. Critical Social Policy, 20 (1): 105-35.

Robson, R., and T. Kessler. 2008. Unsettling sexual citizenship. McGill Law Journal, 53: $537-71$.

Rollins, J. 1990. Entre femmes: Les domestiques et leurs patronnes. Actes de la Recherche en Sciences Sociales, 84: 63-77.

Roseneil, S. 2000. Queer frameworks and queer tendencies: Towards an understanding of postmodern transformations of sexuality. Sociological Research Online, 5 (3): 1-19. http://www.socresonline.org.uk/5/3/roseneil.html

. 2006. On not living with a partner: Unpicking coupledom and cohabitation. Sociological Research Online, 11 (3): 1-21. http://www.socresonline.org.uk/11/3/ roseneil.html

2007. Sutured selves, queer connections: Rethinking intimacy and individualization. In Individualization: A political sociology of contemporary personhood, ed. C. Howard, 117-34. Basingstoke: Palgrave Macmillan. 
2010. Intimate citizenship: A pragmatic, yet radical proposal for a politics of personal life. European Journal of Women's Studies, 17 (1): 77-82.

2012. Using biographical narrative methods and life story methods to research women's movements: FEMCIT. Women's Studies International Forum, 35 (3): 129-31.

Roseneil, S., ed. 2013. Beyond citizenship? Feminism and the transformation of belonging. Basingstoke: Palgrave Macmillan.

Roseneil, S., and S. Budgeon. 2004. Cultures of intimacy and care beyond the family: Personal life and social change in the early twenty first century. Current Sociology, 52 (2): 135-59.

Roseneil, S., I. Crowhurst, T. Hellesund, A. C. Santos, and M. Stoilova. 2008. Policy contexts and responses to changes in intimate life. FEMCIT WP6 Working Paper 1. http://www.femcit.org/files/WP6_WorkingpaperNo1.pdf

Roseneil, S., I. Crowhurst, T. Hellesund, A. C. Santos, and M. Stoilova. 2009. Changing cultural discourses about intimate life: The demands and actions of women's movements and other movements for gender and sexual equality and change, pp.398. FEMCIT WP6 Working Paper 2. http://www.femcit.org/files/WP6_WorkingpaperNo2

Roseneil, S., I. Crowhurst, T. Hellesund, A. C. Santos, and M. Stoilova. 2011. Intimate citizenship and gendered well-being: The claims and interventions of women's movements in Europe. In Transforming gendered well-being in Europe: The impact of social movements, ed. A. Woodward, J. M. Bonvin, and M. Renom, 187-205. Farnham: Ashgate.

Roseneil, S., I. Crowhurst, T. Hellesund, A. C. Santos, and M. Stoilova. 2012. Remaking intimate citizenship in multicultural europe: Experiences outside the conventional family. In Remaki, ed. Beatrice Halsaa, Sasha Roseneil, and Sevil Sümer, 41-69. Basingstoke: Palgrave Macmillan.

Roseneil, S., I. Crowhurst, T. Hellesund, A. C. Santos, and M. Stoilova. 2013. Changing landscapes of heteronormativity: The regulation and normalisation of same-sex sexualities in Europe. Social Politics: International Studies in Gender, State and Society, 20 (2): 165-99.

Russell, P. 2012. Using biographical narrative and life story methods to research women's movements: Sisterhood and after. Women's Studies International Forum, 35 (3): $132-4$.

Saraceno, C., and W. Keck. 2010. Can we identify intergenerational policy regimes in Europe? European Societies, 12 (5): 675-96.

Sarah, E. 1983. Christabel Pankhurst: Reclaiming her power (1880-1958). In Feminist theorists: Three centuries of women's intellectual traditions, ed. D. Spender, 256-84. London: The Women's Press.

Schweitzer, S. 2002. Les femmes ont toujours travaillé: Une histoire du travail des femmes aux xixème et xxème siècles. Paris: Odile Jacob.

Sennett, R. 1998. The corrosion of character: The personal consequences of work in the new capitalism. New York: W. W. Norton \& Company.

Siim, B. 2000. Gender and citizenship: Politics and agency France, Britain, and Denmark. Cambridge: Cambridge University Press.

Siim, B., and J. Squires, eds. 2008. Contesting citizenship. London: Routledge.

Simonazzi, A. 2008. Care regimes and national employment models. Cambridge Journal of Economics, 10: 1-22. 
Stratigaki, M. 2004. The co-optation of gender concepts in EU policies: The case of 'reconciliation of work and family'. Social Politics, 11 (1): 30-56.

Taylor, Y. 2007. Working class lesbian life: Classed outsiders. Basingstoke: Palgrave Macmillan.

Trimberger, E. K. 2005. The new single woman. Boston: Beacon Press.

Uglow, J. 1983. Josephine Butler: From sympathy to theory (1828-1906). In Feminist theorists: Three centuries of women's intellectual traditions, ed. D. Spender, 146-64. London: The Women's Press.

van Houdt, F., S. Suvarieol, and W. Shinkel. 2011. Neoliberal communitarian citizenship-current trends towards 'earned citizenship'. International Sociology, 26 (4): 408-32.

Wasoff, F., L. Jamieson, and A. Smith. 2005. Solo Living, individual and family boundaries: Findings from secondary analysis. In Families in society: Boundaries and relationships, ed. L. McKie, and S. Cunningham-Burley. Bristol: The Policy Press.

Weeks, J. 1998. The sexual citizen. Theory, Culture and Society, 15 (3): 35-52.

Wengraf, T. 2009. BNIM short guide bound with the bnim detailed manual: Interviewing for life histories, lived periods and situation, and ongoing personal experiencing, using the biographic-narrative interpretive method (BNIM) (Version 9.06e).

Widding Isaksen, L., ed. 2010. Global care work: Gender and migration. Lund: Nordic Academic Press.

Wollstonecraft, M. 1792/1985. A vindication of the rights of woman. London: Everyman's Library.

Yuval-Davis, N. 1997. Women, citizenship and difference. Feminist Review, 57: 4-27. 